\title{
高圧燃料ポンプの静音化*
}

\section{Acoustic Improvement of High Pressure Fuel Pump} \\ Masanori WATANABE ${ }^{* 1}$, Kenichiro TOKUO and Hideki MACHIMURA \\ ${ }^{* 1}$ Hitachi LTD, Hitachi Research Laboratory \\ Horiguchi 832-2, Hitachinaka-city, Ibaraki, 312-0034 Japan
}

渡部 眞徳 ${ }^{* 1}$, 徳尾 健一郎 ${ }^{* 1}$, 町村 英紀 $^{* 2}$

\begin{abstract}
Recently, the need for noise reduction of high pressure fuel pump has been increasing due to rising environmental consciousness and improving comfort. Based on our acoustic investigation under idling condition, we identified that the solenoid noise and the compression noise are dominant on high pressure fuel pump. We have investigated the acoustic improvement technique of the solenoid noise for high pressure fuel pump and came to a conclusion that the solenoid noise can be reduced ca. $3 \mathrm{~dB}$ by using optimization of control parameters and a reduced spring force. In this paper, we explain the concept of noise reduction, the control method and the extent of acoustic improvement.
\end{abstract}

Key Words : High Pressure Fuel pump, Acoustic Improvement, Noise Reduction

\section{1. 緒言}

近年，快適性の向上の観点から自動車コンポーネントに対して静肃性のニーズが高まっている．直噴エンジン の主要部品である高圧然料ポンプにおいては，エンジンの回転数が低いアイドリング時の騒音低減が求められて いる. これまでの研究から, 高圧然料ポンプの主な騒音源は, 電磁弁の衝突音と, 高圧脈動に起因する騒音であ ることが分かっている，高圧脈動音に関しては，吐出弁の形状の最適化によって静音化を達成している ${ }^{(1)}$. 従っ て, 本研究は, 電磁弁音をターゲットとして静音化を検討した. 電磁弁音は, 弁の開閉による衝突音であるため, 騒音低減には，弁の応答性を向上し，弁動作を制御して，衝突時の弁速度を遅くする必要がある。そこで，本研 究では，構造と制御の両面から静音化のアプローチを検討した。ただし，コスト低減の観点から制御による方策 をメインにし，構造での変更を最小限にした。本報告では，構造と制御による静音化の手法及び騒音低減効果に ついて述べる.

\section{2. 直噴エンジンの燃料供給システム}

図 1 に直噴エンジンの燃料供給システムの概要を示す。本ポンプの主な構成部品はカム，プランジャ，電磁ア クチュエータを備えた吸入弁, 吐出弁である. カムはエンジンのカムシャフト等の回転動力を用いて駆動され, プランジャを往復運動させる. 本ポンプには, 燃料タンク内にあるフィードポンプから然料が供給され, プラン ジャが下降する時に吸入弁を開き加圧室に流入される．プランジャが上昇する時に，吸入弁を閉じ加圧室内の然 料が圧縮され, 圧力上昇によって吐出弁が開き, 高圧燃料が吐出される. 吐出された然料はコモンレールを経て インジェクタから噴射される. 本ポンプではエンジン燃焼に必要な燃料を吐出するよう ECU(Engine Control Unit) により流量制御を行っている. 吸入弁は電磁アクチュエータによって閉弁動作を電気的に制御できる構造となっ ており, 電磁弁と呼ばれる. プランジャ下降時に加圧室に流入した然料は, プランジャ上昇時に, 吸入弁が開弁

* 原稿受付 2012 年 10 月 18 日 改訂原稿受付 2013 年 7 月 19 日

${ }^{* 1}$ 正員, (株) 日立製作所 日立研究所（广312-0034 茨城県ひたちなか市堀口 832-2）

*2 正員, 日立オートモティブシステムズ(株)

E-mail: masanori.watanabe.or@hitachi.com 
保持されていれば吸入側へ戻され，吸入弁が閉弁すれば加圧室内で加圧され吐出される．プランジャ上昇時に吸 入弁が閉弁されるタイミングを制御して, 吸入側へ戻される燃料と加圧される燃料の割合を変えることによって, 吐出される流量を制御することができる.

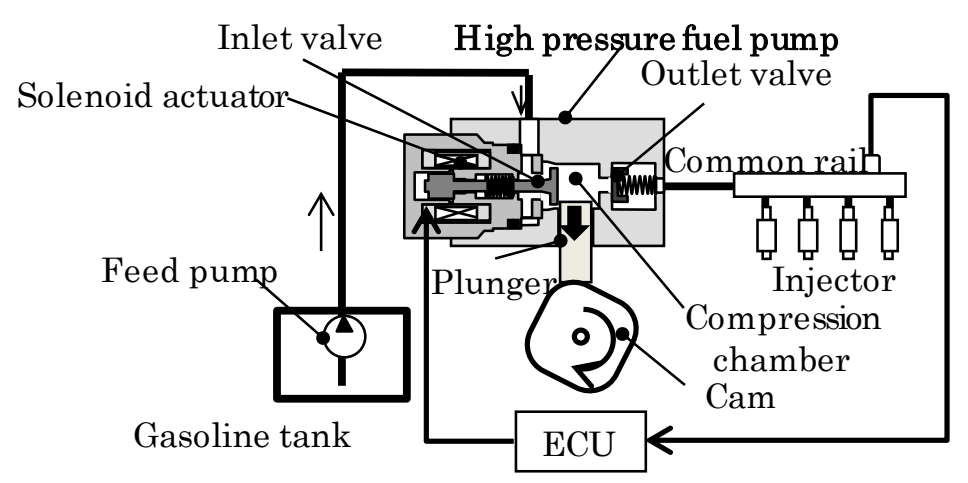

Fig.1 Schematic drawing of direct injection fuel system

\section{3. 高圧燃料ポンプの騒音の特徴}

図 2 に実車での騷音測定位置を示す．同図に示すように遠距離音場用と近接音測定用の 2 つを用意した．遠距 離測定用は，ポンプ本体から前方に $60 \mathrm{~cm}$ ，上方向に $60 \mathrm{~cm}$ ，直線距離で約 $80 \mathrm{~cm}$ の位置に設置し，近接音測定用 は，ポンプの直上 $10 \mathrm{~cm}$ の位置に設置し，ボンネットを開けてエンジンカバーを取り外した状態で，アイドリン グ運転時に実施した.

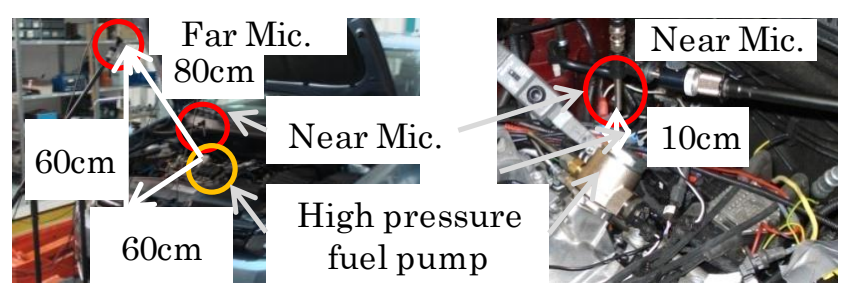

Fig.2 Measurement position of noise

図 3 に遠距離測定用マイク位置での騒音の STFT(Short Time Fourier Transform)結果を示す.この結果から, 1.0kHz $\sim 2.0 \mathrm{kHz}$ と $4.0 \mathrm{kHz} \sim 5.0 \mathrm{kHz}$ の 2 つ周波数帯域が支配的であることが分かる. また，同図の圧力測定結果から， 前者は加圧行程, 後者は吸入行程に同期して発生していることが分かる. これまでの研究から, 前者は加圧行程 時に発生する高圧脈動音であり，後者は吸入工程時に電磁弁（吸入弁）が開弁する衝突音であることが分かって いる(1)，そこで，本研究では後者の電磁弁音の低減について検討した.

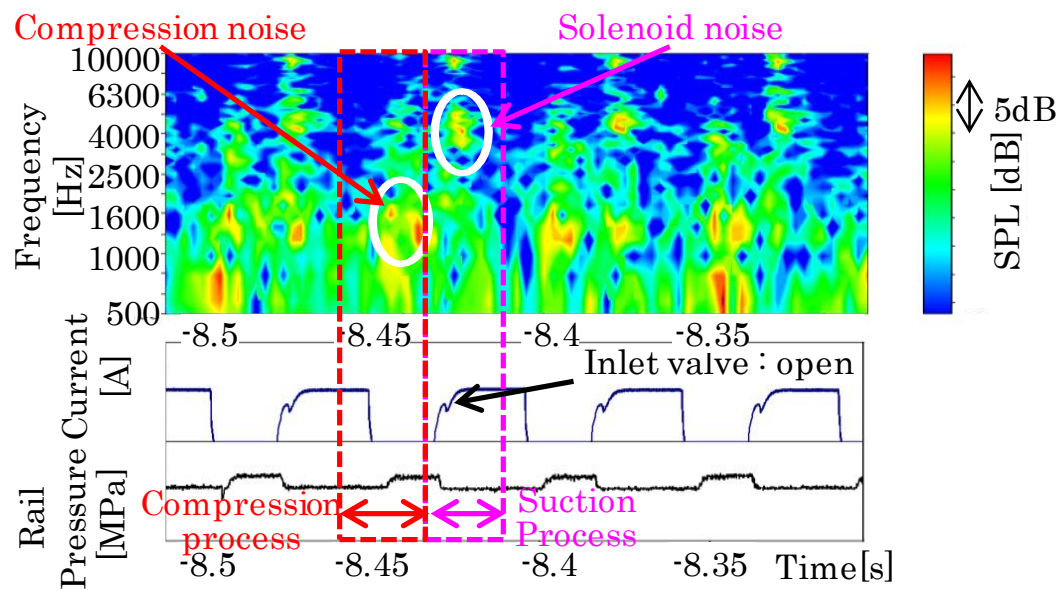

Fig.3 Acoustic measurement result 


\section{4. 電磁弁音の低減}

図 4 に電磁弁の構造を示す，左図は弁が閉じた状態で，右図は開いた状態である，本研究対象の電磁弁はノー マルクローズ式電磁弁である.ノーマルクローズ式とは, 通常の電動アクチュエータ非通電時に吸入弁が閉弁し, 通電時に開弁する方式である，電動アクチュエータ非通電時は，ばねの荷重によって吸入弁は閉弁方向（図中左 方向）に付勢される.アンカーは吸入弁部材と一体に形成されており, 通電されると，アンカーとコアとの間に 磁気吸引力が発生し，アンカーを開弁方向（図中右方向）に付勢する力が働く(2). 電磁弁の衝突音は，アンカー がコアに衝突する時に発生する，この衝突音を低減するためには，磁気吸引力を必要最小限に抑え，アンカーが コアに衝突する速度を低減する必要がある. 本研究では, 必要な磁気吸引力を小さくするためにばね荷重を低減 し，衝突速度を緩和するために電流值を制御した。

Solenoid coil Spring force Outlet valve Magnetic force Fuel flow
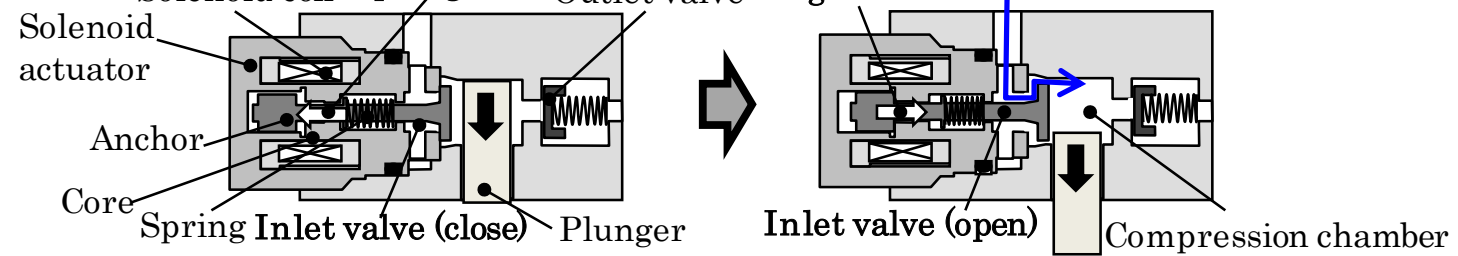

Fig.4 Structure of solenoid valve

ばね荷重を低減すると弁の応答性が向上する反面，弁のシール性劣化などのロバスト性が低減する可能性があ るため, 本研究では，それを鑑みてロバスト性確保の面からばね荷重の低減率を現状から $60 \%$ とした．図 5 に現 状とばね荷重低減時での最小駆動電流の比較を示す，同図より，ばね荷重を $60 \%$ 低減することで駆動電流を現状 の $100 \%$ に対して約 30\%まで低減できることが分かる.

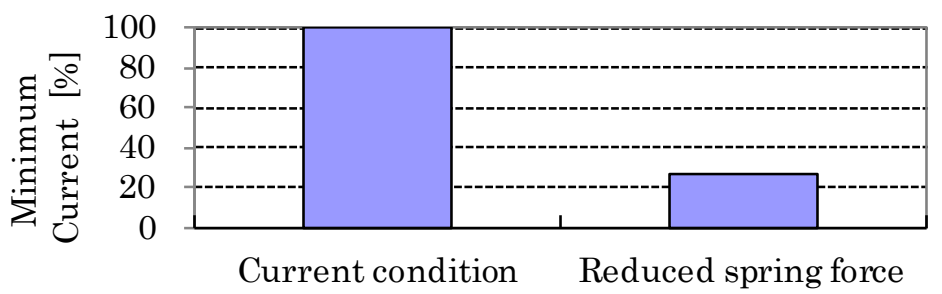

Fig.5 Comparison of minimum current between current condition and reduced spring force

次に, 電流值を制御する方法として, 静音制御方式を考案し適用した. 図 6 に従来の制御方法と静音制御方法 の概念図を示寸，従来手法とは図 4 に示寸電磁弁を用いた制御方法であり, 図 6 に示寸ように通電時に磁気吸引 力によって弁が開弁方向に移動するのが特徵である. 本制御方法は従来方法をべースに静音のための電流制御を 施したものである. 従来手法では, 吸入工程の中盤でコイルに通電していたが，本制御方法では，吸入工程早期 にコイル通電を開始する，それにより吸入工程時に吸入する開弁方向の流体力を利用することができ，少ない電 磁力で開弁操作ができるようになる，更に，吸入弁が開弁動作をはじめる時に高い電流を与え，衝突する前には 低い電流を与える，これにより，アンカーの初期動作を確実に行いかつ衝突前の期間でのアンカーの速度を抑え ることができるので衝突時の騷音を低減できる.

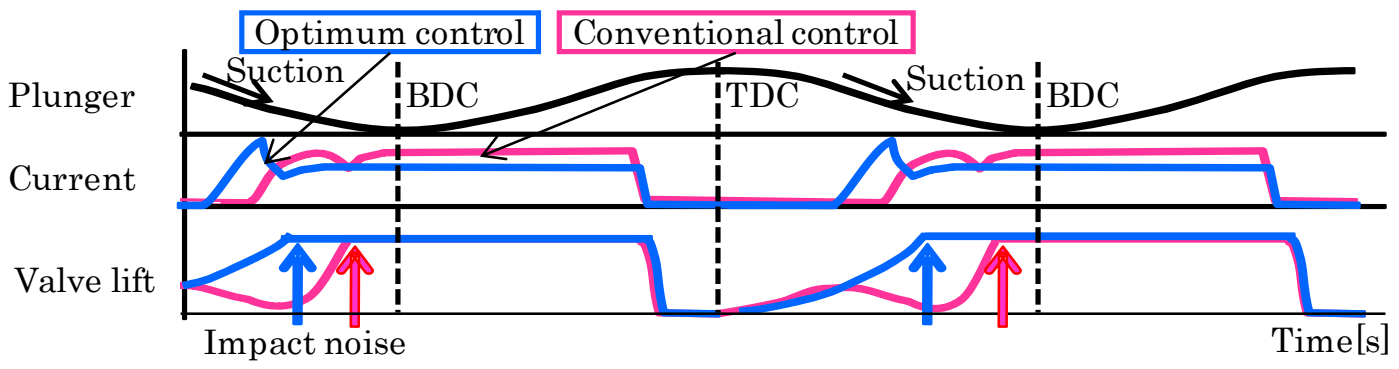

Fig. 6 Concept of noise reduction 
図 7 に本制御方式で用いる制御パラメータ(PON,FON 及び PWM)を示寸.ここで, プランジャが上死点 (TDC) の位置を基準として, 電流を与え始めるカム回転角を PON（Pulse ON）(deg) と定義する，通電開始後，100\%通 電し，素早い電流立ち上がりを促す期間を FON(First ON) (ms) と定義する. その後, 周期的(パルス的)に電流の ON と OFF を繰り返す PWM (Pulse Width odulation)制御を行い, その Duty 比(ある時間区間に占める ON の割合) により電流を制限する．ここではその PWM duty 比を PWM(\%)と定義する. 従って, PON は弁体が動き始める夕 イミングを, FON は弁体の動き始めの速度を, PWM は弁体の後半の速度をそれぞれ制御していると考えられる. 本制御コンセプトは, 弁体に働く流体力や, 電気, 機械的遅れなど, 定量的に予測困難な要素の影響を受け, 机 上で制御定数を決めるのは困難であるため, 実車を用いてパラメータ最適化を行った. 最適化にはポンプコント ローラ(3)を用いた. 本コントローラは, エンジンから出力されるクランク／カム信号, 燃料圧力を読み取り, 上 記のパラメータに合わせて任意のポンプ駆動波形を生成することができる，そこで，本試験ではエンジン制御は 既存の ECU を用い, ポンプの駆動信号を本コントローラから与えて，3つの制御パラメータ (PON, FON 及び PWM)の最適化を行った.

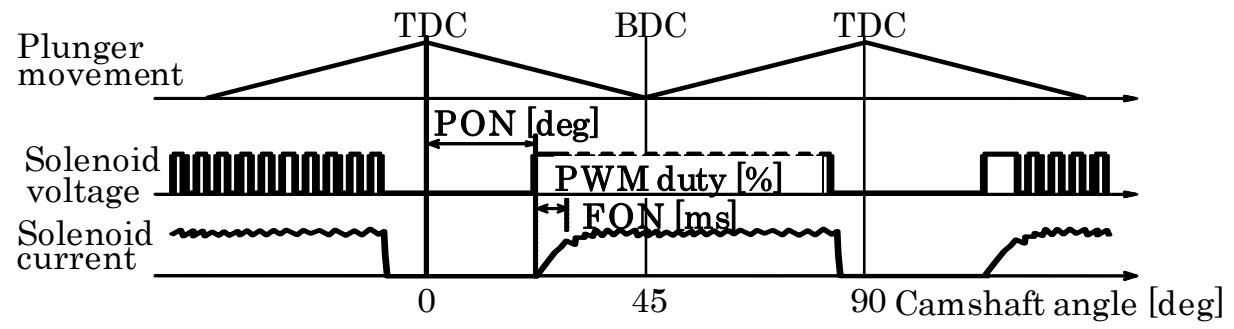

Fig.7 Control parameters

図 8 にPON と FON の PWM をスイープした時の騒音に対する感度を示す. 左図はFONを固定して PON を現 状から 5 段階でスイープした場合, 右図はPON を固定しFON を現状から 3 段階でスイープした場合のPMW の 違いによる騒音レベルを示している. 同図で, PWM が高い場合(図の右方向)にはPON と FON を変化させてもほ とんど騒音レベルに変化がないが，PWM が低い場合(図の左方向)にはPON と FON の変化(低減)に追従して騒音 レベルが低減(最大約 4dB) していることが分かる．このことは，PWM を下げることによって，PON と FON の騒 音の感度を上げることができ, それらの值の変更で現行レベルより騒音低減が可能となることを示している.
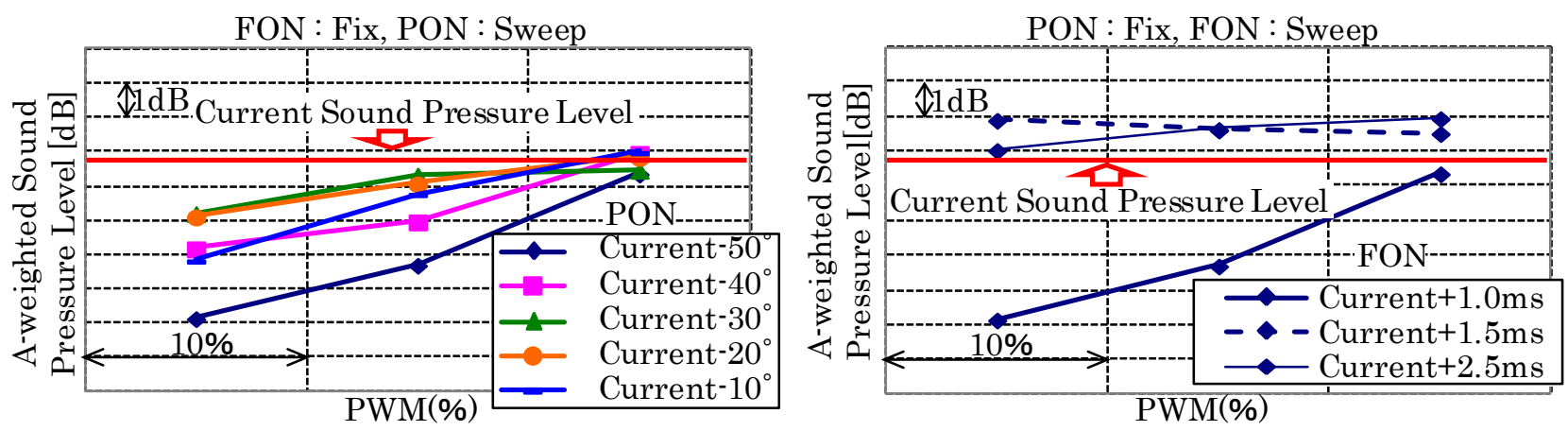

Fig. 8 Sensitivity to noise of PON and FON for swept PWM

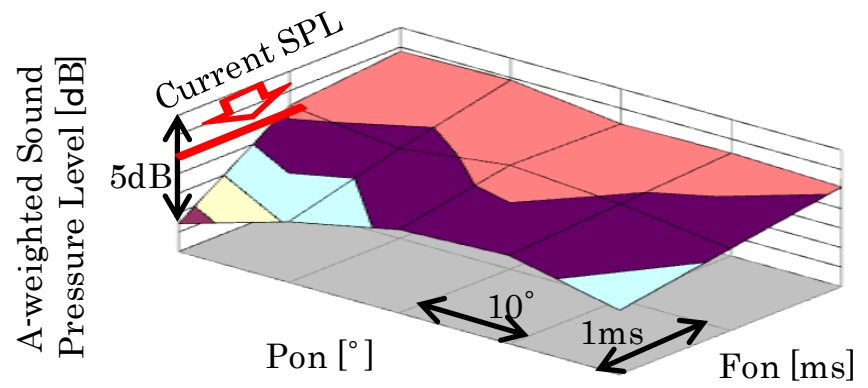

Fig.9 Sound pressure level for swept PON and FON under minimum PWM 
図 9 は，荷重低減ばね設置時に PMW を最も下げた状態で，PON と FON をスイープした時の騒音レベルの測 定結果である.PON と FON ともに小さくする方が騒音の低減効果は高いことが分かる.しかしながら，これら の制御パラメータはポンプ動作に影響を及ぼすため，ポンプが正常に吐出動作出来る範囲でパラメータを最適化 する必要がある，そこで，実際には，電磁弁動作を保証できる下限值を把握することとした．最低動作限界は， PON，FON 及びPWM の3つのパラメータが相互に影響するため，本研究では，まず，各 PON，FON の組合せ で，ポンプが正常に吐出動作できる下限の PWM を実験的に求め, 次に，ポンプが正常に吐出動作できる状態を 確保して，最適な制御パラメータの組み合わせを決定した.

図 10 に荷重低減ばねと電流制御パラメータ最適化時の騒音レベルの測定結果を示し，図 11 に STFT 結果を示 す.これらの図には, 現行量産品での結果を同時に示している. 図 10 より, 現行量産に比べて騒音を約 $3 \mathrm{~dB}$ 低 減できていることが分かる，なお，今回使用したポンプは，電磁弁の衝突音が支配的であるため，本低減効果は 衝突音の低減効果であると考えられる。図 11 の STFT 結果においても，4kHz 近傍の弁の衝突に起因する高周波 騒音が低減できていることが分かる，同図には，電流值も同時に示している．電流の波形は，従来(左図)のよう に，ゆっくりと電流を上げていくより，今回(右図)のように最初に電流を大きく流し，弁が衝突する手前で電流 をカットして, ゆっくり衝突させること, つまり, “ソフトランディング”が騒音低減に有効であることが分かる.

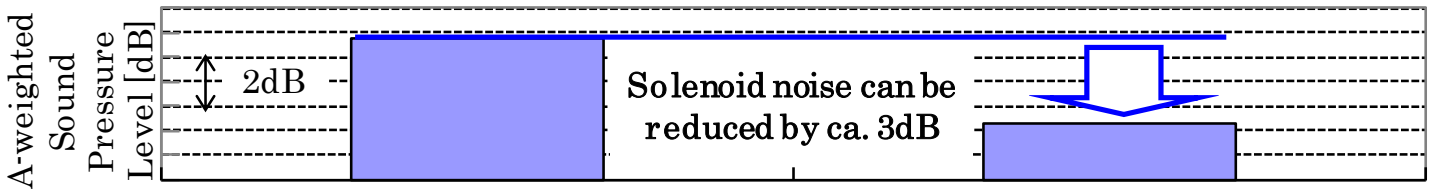

Current condition Reduced spring force + Control parameter optimization

Fig.10 Sound pressure level of reduced force spring and control parameter optimization
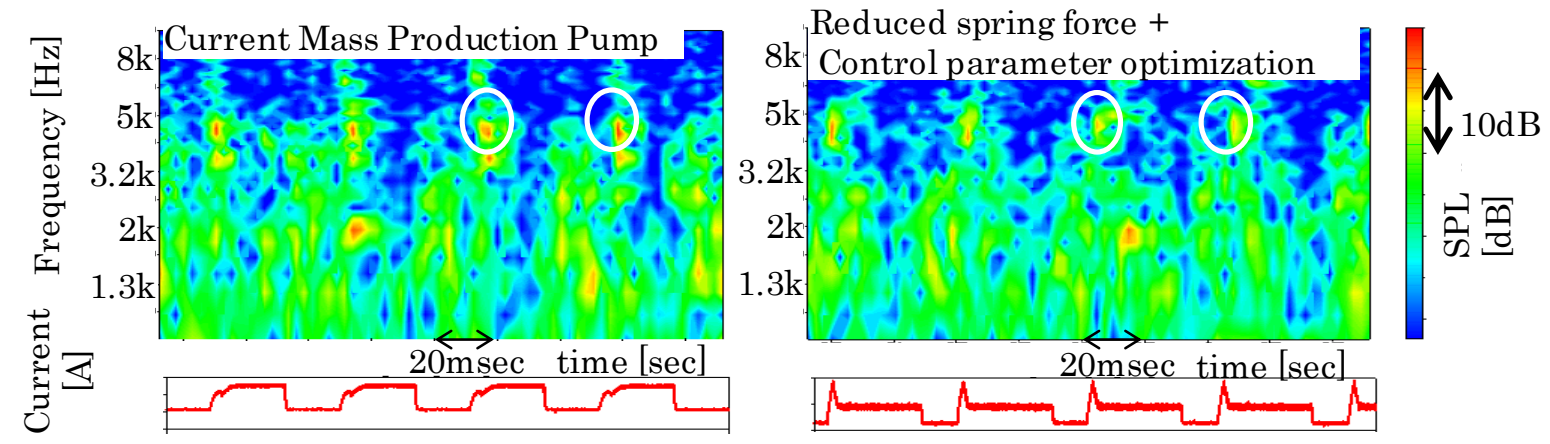

Fig.11 STFT of reduced force spring and control parameter optimization

\section{5. 結 言}

高圧燃料ポンプの電磁弁音の低減を目的として，必要とする電磁吸引力の低減および電流の制御方法を検討し た結果以下の結論を得た.(1)ばね荷重を低減することにより弱い電磁力に対しても高応答な弁駆動を可能にした. (2)電磁弁のアンカーがコアに衝突する直前に駆動電流を低減する静音制御手法を確立した. (3)ポンプコントロー ラにより駆動電流の制御パラメータ $(\mathrm{PON}, \mathrm{FON}$ 及び PWM)を最適化した. (4)上記の結果, 電磁弁音を現行量産品 から $3 \mathrm{~dB}$ 低減できた.

\section{文献}

(1) 徳尾健一郎, 有冨俊亮, 今野仁志, 町村英紀, “ロバストデザインによるポンプ脈動音の低減”, 日本機械学会 演論文集 B 編, Vol. 78, No. 776 (2012), pp2054-2061.

(2) 徳尾健一郎, 有冨俊亮, 臼井悟史, “直噴ガソリンエンジン用高圧燃料ポンプの開発”, 日本機械学会演論文集 B 編, Vol. 77, No. 779 (2011).

(3) Jonathan Borg, Kenichiro Tokuo, Shiro Yamaoka and Masanori Watanabe, "On the simulation and control of a gasoline direct injection pump", SIA (Societe des Ingenieurs de l'Automobile) European Mechatronics Meeting. Paris (2009). 